\title{
UJI EFEKTIVITAS PUPUK ORGANONITROFOS DAN KOMBINASINYA DENGAN PUPUK ANORGANIK TERHADAP SERAPAN HARA DAN PRODUKSI TANAMAN JAGUNG (Zea Mays L.) PADA MUSIM TANAM KE DUA DI TANAH ULTISOLS GEDONG MENENG
}

\author{
Metha Deviana, Dermiyati, Jamalam Lumbanraja, \\ Ainin Niswati \& Sutopo Ghani Nugroho \\ Jurusan Agroteknologi, Fakultas Pertanian Universitas Lampung \\ Jl. Prof. Soemantri Brodjonegoro, No. 1, Bandar Lampung 35145 \\ E-mail: Methadeviana91@yahoo.com
}

\begin{abstract}
ABSTRAK
Pupuk Organonitrofos merupakan pupuk organik baru yang terbuat dari pencampuran kotoran sapi dengan batuan fosfat alam yang diperkaya mikroorganisme penambat $\mathrm{N}$ dan pelarut $\mathrm{P}$. Penelitian ini bertujuan untuk mengetahui efektivitas pupuk Organonitrofos dan kombinasinya dengan pupuk anorganik terhadap pertumbuhan, serapan hara, dan produksi tanaman jagung. Penelitian ini menggunakan Rancangan Acak Kelompok (RAK) terdiri dari 6 perlakuan yaitu A (kontrol), B (900 kg urea

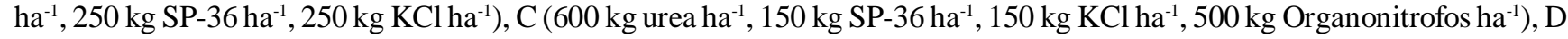
$\left(150 \mathrm{~kg}\right.$ urea ha ${ }^{-1}, 50 \mathrm{~kg} \mathrm{SP}-36 \mathrm{ha}^{-1}, 100 \mathrm{~kg} \mathrm{KCl} \mathrm{ha}^{-1}, 1.000 \mathrm{~kg}$ Organonitrofos ha-1), E (100 kg urea ha-1, $50 \mathrm{~kg} \mathrm{SP-36} \mathrm{ha-1,} 100 \mathrm{~kg}$ $\mathrm{KCl} \mathrm{ha}^{-1}, 2.000 \mathrm{~kg}$ Organonitrofos ha $\left.\mathrm{a}^{-1}\right)$, dan F (3.000 kg Organonitrofos ha $\left.{ }^{-1}\right)$ dengan 3 ulangan. Hasil penelitian menunjukkan bahwa pupuk Organonitrofos mampu mengurangi penggunaan pupuk anorganik. Berdasarkan perhitungan standar deviasi kombinasi antara pupuk anorganik dan Organonitrofos pada perlakuan D dengan dosis $150 \mathrm{~kg} \mathrm{urea} \mathrm{ha}{ }^{-1}, 50 \mathrm{~kg} \mathrm{SP}^{2} \mathrm{ha}^{-1}, 100$ $\mathrm{kg} \mathrm{KCl} \mathrm{ha}{ }^{-1}, 1.000 \mathrm{~kg}$ Organonitrofos $\mathrm{ha}^{-1}$ menunjukkan hasil pertumbuhan, produksi, serta serapan hara $\mathrm{N}$, $\mathrm{P}$, dan $\mathrm{K}$ total tertinggi. Perlakuan D juga paling efektif terhadap biomass total tanaman jagung berdasarkan perhitungan Relative Agronomic Effectiveness yaitu sebesar 125,33\%. Serapan hara N, P, dan K berkorelasi dengan tinggi tanaman, bobot pipilan kering serta bobot berangkasan tanaman, kecuali antara serapan $\mathrm{P}$ dengan tinggi tanaman.
\end{abstract}

Kata kunci : Jagung, kombinasi pupuk, Organonitrofos, serapan hara.

\section{PENDAHULUAN}

Jagung merupakan salah satu produk pertanian yang banyak dihasilkan di Indonesia. Menurut Badan Pusat Statistik (2013), produksi jagung di Provinsi Lampung tahun 2009 sebesar 2,06 juta ton dengan produktivitas sebesar $47,58 \mathrm{ku} \mathrm{ha}^{-1}$ naik menjadi 2,126 juta ton dengan produktivitas $47,52 \mathrm{ku} \mathrm{ha}^{-1}$ pada tahun 2010. Sedangkan pada tahun 2012 produksi jagung menurun menjadi 1,760 juta ton dengan produktivitas sebasar 48,86 ku ha-1. Penurunan produksi ini disebabkan oleh berkurangnya luas panen sebesar 66,59 ribu hektar dibandingkan tahun sebelumnya (Badan Pusat Statistik, 2013). Selain itu, faktor lain yang mempengaruhi penurunan produksi tanaman jagung yaitu kesuburan tanah yang rendah.

Tanah di Provinsi Lampung umumnya didominasi tanah Ultisols. Tanah Ultisols merupakan tanah yang memiliki kandungan hara rendah. Prasetyo dan Suriadikata (2006) menyatakan bahwa Tanah Ultisols umumnya memiliki kejenuhan basa $<35 \%$, pH tanah umumnya agak masam hingga sangat masam, serta memiliki kapasitas tukar kation yang tergolong rendah. Kandungan unsur hara Tanah Ultisols yang rendah dapat ditangani dengan intensifikasi. Salah satu cara intensifikasi yang dapat dilakukan yaitu melalui pemupukan.

Selama ini, petani cenderung memiliki ketergantungan yang tinggi terhadap pupuk anorganik. Penggunaan pupuk anorganik secara terus menerus dalam jangka panjang dapat meningkatkan kandungan $\mathrm{H}^{+}$sehingga menurunkan $\mathrm{pH}$ tanah (Yusnaini, 2009) dan apabila dibiarkan berlarut-larut kesuburan alami tanah akan mengalami penurunan (Suratmi, 2009). Sedangkan penggunaan pupuk organik dapat memperbaiki sifat fisik, kimia dan biologi tanah sehingga dapat meningkatkan kesuburan tanah. Pengaplikasian pupuk organik dapat mengurangi penggunaan dan meningkatkan efisiensi penggunaan pupuk anorganik (Ma dkk., 2006) juga menyumbangkan unsur hara bagi tanaman serta meningkatkan serapan unsur hara oleh tanaman (Wigati dkk., 2006).

Berdasarkan uraian tersebut, maka diperlukan pupuk organik yang mampu menyediakan unsur hara 
yang memadai. Nugroho, dkk. (2012) telah memformulasikan pupuk Organomineral NP (Organonitrofos) yang terbuat dari pencampuran 20\% batuan fosfat alam dan $80 \%$ kotoran sapi yang telah diperkaya mikroorganisme penambat $\mathrm{N}$ dan pelarut $\mathrm{P}$ (Nugroho dkk., 2013). Pupuk ini diharapkan dapat menjadi salah satu pemecahan masalah dalam memenuhi kebutuhan pupuk, terutama di Provinsi Lampung.

Penelitian ini merupakan penelitian lanjutan yang dilaksanakan pada musim tanam ke dua (musim penghujan). Penelitian ini bertujuan untuk mengetahui pengaruh pemberian pupuk Organonitrofos dan kombinasinya dengan pupuk anorganik terhadap pertumbuhan, serapan hara, dan produksi tanaman jagung (Zea mays L.), mengetahui efektivitas dan keekonomisan pupuk Organonitrofos dan kombinasinya dengan pupuk anorganik terhadap produksi tanaman jagung (Zea mays L.), dan mengetahui keeratan hubungan (korelasi) antara serapan hara dengan pertumbuhan dan produksi tanaman jagung (Zea mays L.).

\section{BAHAN DAN METODE}

Penelitian ini dilakukan di Laboratorium Lapangan Terpadu Universitas Lampung dan Laboratorium Ilmu Tanah pada bulan November 2012 sampai Maret 2013. Lahan yang digunakan dalam penelitian ini merupakan lahan bekas pertanaman jagung pada musim tanam pertama yang pada musim tanam kedua ini diberi perlakuan yang sama (Septima, 2013).

Penelitian ini menggunakan Rancangan Acak Kelompok (RAK) terdiri dari 6 perlakuan dengan 3 ulangan. Perlakuan berdasarkan dosis pupuk yang diberikan yaitu : $\mathrm{A}=$ tanpa pemupukan (kontrol); $\mathrm{B}=$ $900 \mathrm{~kg}$ urea ha ${ }^{-1}, 250 \mathrm{~kg} \mathrm{SP}-36 \mathrm{ha}^{-1}, 250 \mathrm{~kg} \mathrm{KCl} \mathrm{ha}^{-1}$; $\mathrm{C}=600 \mathrm{~kg}$ urea ha ${ }^{-1}, 150 \mathrm{~kg} \mathrm{SP}-36 \mathrm{ha}^{-1}, 150 \mathrm{~kg} \mathrm{KCl}^{-}$ ${ }^{1}, 500 \mathrm{~kg}$ Organonitrofos ha ${ }^{-1} ; \mathrm{D}=150 \mathrm{~kg}$ urea ha ${ }^{-1}, 50$ kg SP-36 ha ${ }^{-1}, 100 \mathrm{~kg} \mathrm{KCl} \mathrm{ha}^{-1}, 1.000 \mathrm{~kg}$ Organonitrofos ha $^{-1} ; \mathrm{E}=100 \mathrm{~kg}$ urea ha ${ }^{-1}, 50 \mathrm{~kg} \mathrm{SP}-36 \mathrm{ha}^{-1}, 100 \mathrm{~kg} \mathrm{KCl}$ ha $^{-1}, 2.000 \mathrm{~kg}$ Organonitrofos $\mathrm{ha}^{-1} ; \mathrm{F}=3.000 \mathrm{~kg}$ Organonitrofos ha-1.

Tanaman jagung ditanam dengan jarak tanam 75 $\mathrm{cm} \times 25 \mathrm{~cm}$ dengan luasan petak $3 \mathrm{~m} \times 3 \mathrm{~m}$. Pengaplikasian pupuk urea dilakukan sebanyak dua kali yaitu, aplikasi pertama sebanyak 50\% dilakukan pada 2 MST berbarengan dengan pupuk SP-36, $\mathrm{KCl}$, dan pupuk Organonitrofos. Sedangkan aplikasi kedua (50\%) dilakukan pada saat tanaman berbunga. Pemanenan dilakukan 120 hari setelah tanam, jagung dipipil dan diukur kadar airnya kemudian dikonversi pada kadar air $15 \%$. Pengambilan contoh tanah dilakukan secara komposit untuk masing-masing perlakuan. Contoh tanah diambil pada saat sebelum tanam dan sesudah dilakukan pemanenan. Pengambilan sampel tanaman dilakukan setelah jagung dipanen.

Pengamatan dilakukan terhadap bobot berangkasan, bobot pipilan kering pada kadar air 15\%, bobot seratus butir berdasarkan kadar air 15\%, serapan $\mathrm{N}$, P, dan $\mathrm{K}$ tanaman berdasarkan bobot kering, dan uji korelasi. Pengamatan juga dilakukan terhadap tinggi tanaman dan jumlah daun; analisis tanah, serta uji efektivitas dan uji ekonomis pupuk Organonitrofos. Uji efektivitas pupuk dihitung menggunakan RAE dengan membandingkan antara kenaikan hasil karena penggunaan pupuk Organonitrofos dengan kenaikan hasil akibat penggunaan pupuk anorganik dikalikan 100\% (Permentan No. 70, tahun 2011). Sedangkan uji ekonomis pupuk organonitrofos dilakukan dengan menghitung ratio penerimaan dengan membandingan antara penerimaan total dengan biaya total Soekartawi (1995).

\section{HASIL DAN PEMBAHASAN}

Tanah Ultisols Gedong Meneng yang dilakukan pada penelitian ini memiliki $\mathrm{pH}$ agak masam. Kandungan C-organik tergolong rendah sampai sedang, N-total tergolong sedang, P-tersedia tergolong sangat rendah sampai sedang, dan K-dd tergolong tinggi (Tabel 1) (Septima, 2013). Sedangkan pupuk Organonitrofos yang digunakan memiliki kandungan $\mathrm{pH} 7,28$. Adapun kandungan C-organik pupuk Organonitrofos ini ialah $2,83 \%$ dan $\mathrm{N}$-total sebesar $0,35 \%(\mathrm{C} / \mathrm{N}=8,09)$. Kandungan hara $\mathrm{P}$ sebesar $0,31 \%$ dan $\mathrm{K}$ total sebesar $0,19 \%$ (Tabel 2).

Apabila dibandingkan dengan kriteria persyaratan teknis SNI (Tabel 2) kandungan hara makro pupuk Organonitrofos tersebut belum sesuai dengan kriteria persyaratan pupuk organik. Sehingga perlu dilakukan reformulasi dengan menggunakan bahan baku yanag memiliki kandungan hara lebih tinggi sehingga kandungan hara pupuk Organonitrofos sesuai dengan kriteria persyaratan teknis SNI.

Hasil penelitian menunjukkan bahwa semua perlakuan memberikan pengaruh yang tidak berbeda nyata terhadap tinggi tanaman dan jumlah daun. Namun, berdasarkan perhitungan standar deviasi dosis kombinasi $150 \mathrm{~kg}$ urea ha ${ }^{-1}, 50 \mathrm{~kg} \mathrm{SP}-36 \mathrm{ha}^{-1}, 100 \mathrm{~kg} \mathrm{KCl} \mathrm{ha}^{-1}$, $1.000 \mathrm{~kg}$ Organonitrofos $\mathrm{ha}^{-1}$ menunjukkan tinggi tanaman dan jumlah daun tertinggi walaupun tidak berbeda nyata dengan perlakuan lainnya (Gambar 1 dan 2). Hal ini diduga disebabkan tanah yang digunakan memiliki kandungan unsur hara yang cukup memadai, 
Tabel 1. Hasil analisis kimia tanah awal (akhir musim tanam I) (Septima, 2013).

\begin{tabular}{cccccc}
\hline Perlakuan & N-total (\%) & P-tersedia (ppm) & K-dd $\left(\mathrm{cmol} \mathrm{kg}^{-1}\right)$ & $\mathrm{pH}\left(\mathrm{H}_{2} \mathrm{O}\right)$ & C-org $(\%)$ \\
\hline A & $0,17(\mathrm{R})$ & $7,18(\mathrm{SR})$ & $0,51(\mathrm{~S})$ & $6,04(\mathrm{AM})$ & $1,50(\mathrm{R})$ \\
B & $0,33(\mathrm{~S})$ & $20,01(\mathrm{~S})$ & $0,84(\mathrm{~T})$ & $6,07(\mathrm{AM})$ & $1,98(\mathrm{R})$ \\
C & $0,28(\mathrm{~S})$ & $21,65(\mathrm{~S})$ & $0,84(\mathrm{~T})$ & $6,14(\mathrm{AM})$ & $2,08(\mathrm{~S})$ \\
D & $0,24(\mathrm{~S})$ & $9,68(\mathrm{SR})$ & $0,76(\mathrm{~T})$ & $6,13(\mathrm{AM})$ & $2,03(\mathrm{~S})$ \\
E & $0,27(\mathrm{~S})$ & $11,33(\mathrm{R})$ & $0,81(\mathrm{~T})$ & $6,11(\mathrm{AM})$ & $2,24(\mathrm{~S})$ \\
F & $0,28(\mathrm{~S})$ & $17,11(\mathrm{R})$ & $0,80(\mathrm{~T})$ & $6,08(\mathrm{AM})$ & $2,20(\mathrm{~S})$ \\
\hline
\end{tabular}

Keterangan: $\mathrm{A}=$ tanpa pemupukan (kontrol); $\mathrm{B}=900 \mathrm{~kg}$ urea ha ${ }^{-1}, 250 \mathrm{~kg} \mathrm{SP}-36 \mathrm{ha}^{-1}, 250 \mathrm{~kg} \mathrm{KCl} \mathrm{ha-1} ; \mathrm{C}=600 \mathrm{~kg}$ urea ha-1, $150 \mathrm{~kg} \mathrm{SP}^{-36} \mathrm{ha}^{-1}, 150 \mathrm{~kg} \mathrm{KCl} \mathrm{ha}^{-1}, 500 \mathrm{~kg}$ Organonitrofos ha' ${ }^{-1}$ D= $150 \mathrm{~kg}$ urea ha ${ }^{-1}, 50$ $\mathrm{kg} \mathrm{SP}-36 \mathrm{ha}^{-1}, 100 \mathrm{~kg} \mathrm{KCl} \mathrm{ha}^{-1}, 1.000 \mathrm{~kg}$ Organonitrofos ha- ${ }^{-1}$; $=100 \mathrm{~kg}$ urea ha-1, $50 \mathrm{~kg} \mathrm{SP}-36$ ha$1,100 \mathrm{~kg} \mathrm{KCl}$ ha-1, $2.000 \mathrm{~kg}$ Organonitrofos ha-1; $\mathrm{F}=5.000 \mathrm{~kg}$ Organonitrofos ha ${ }^{-1}$. SR=sangat rendah, $\mathrm{R}=$ rendah, $\mathrm{S}=$ sedang, $\mathrm{T}=$ tinggi, $\mathrm{AM}=$ agak masam $(\mathrm{FAO}, 1983)$.

Tabel 2. Kandungan Hara pupuk Organinitrofos

\begin{tabular}{llcc}
\hline \multicolumn{1}{c}{ Jenis Analisis } & Metode Ana lisis & $\begin{array}{c}\text { Pupuk } \\
\text { Organonitrofos }\end{array}$ & $\begin{array}{c}\text { Kriteria persyaratan teknis } \\
\text { SNI }\end{array}$ \\
\hline $\mathrm{pH}\left(\mathrm{H}_{2} \mathrm{O}\right)$ & Electromagnetik & 7,28 & $4-9$ \\
$\mathrm{C}$-organik $(\%)$ & Walkey and Black & 2,83 & $\geq 15$ \\
$\mathrm{~N}$-total $(\%)$ & Kjeldhal & 0,35 & - \\
$\mathrm{C} / \mathrm{N}$ & & 8,09 & $15-25$ \\
$\mathrm{P}$-tersed $\mathrm{P}_{2} \mathrm{O}_{5}(\%)$ & $\mathrm{Bray}$ & 0,31 & - \\
$\mathrm{K}$-total $\mathrm{HCl} 25 \%(\%)$ & $\mathrm{NH}_{4} \mathrm{OAc}$ & 0,19 & - \\
Hara makro $\left(\mathrm{N}+\mathrm{P}_{2} \mathrm{O}_{5}+\mathrm{K}_{2} \mathrm{O}\right)(\%)$ & & 0,85 & $\geq 4$ \\
\hline
\end{tabular}

sehingga pada perlakuan kontrol (tanpa pemupukan) pertumbuhan tinggi tanaman dan jumlah daun tidak berbeda nyata dengan perlakuan pemupukan. Lahan yang digunakan merupakan lahan yang baru dibuka yang sebelumnya ditumbuhi rerumputan/semak belukar sehingga kandungan bahan organiknya masih tinggi. Kandungan unsur hara yang memadai ini diduga berasal dari dekomposisi bahan organik yang bersumber dari jaringan tanaman yang telah mati. Yulnafatmawita, dkk. (2011) menyatakan bahwa peningkatan bahan organik dapat berasal dari akar tanaman yang membusuk atau eksudat akar dari tanaman yang masih hidup. Bahan organik yang telah terdekomposisi mampu meningkatkan kandungan unsur hara dalam tanah.

Hasil analisis ragam menunjukkan bahwa pemupukan juga memberikan pengaruh yang tidak berbeda nyata terhadap bobot pipilan kering tanaman jagung. Namun, berdasarkan perhitungan standar deviasi, perlakuan D dengan dosis $150 \mathrm{~kg}$ urea ha ${ }^{-1}+50$ kg SP-36 ha ${ }^{-1}+100 \mathrm{~kg} \mathrm{KCl} \mathrm{ha-1}+1.000 \mathrm{~kg}$ Organonitrofos ha ${ }^{-1}$ menunjukkan bobot pipilan kering tertinggi sebesar 7,73 t ha-1 (Tabel 3). Data tersebut menunjukkan rata-rata potensi hasil yang diperoleh jagung varietas hibrida (BISI-2) pada penelitian ini tidak jauh berbeda dengan rata-rata potensi hasil rekomendasi yaitu sebesar 8,9 t ha-1 (Adnan dkk., 2010). Hal ini diduga disebabkan pupuk Organonitrofos dan anorganik yang diaplikasikan pada musim pertama telah terurai, sehingga pada musim tanam kedua unsur hara menjadi tersedia bagi tanaman.

Nursyamsi, dkk. (1996) menyatakan bahwa pemberian kombinasi pupuk anorganik dan kompos dapat meningkatkan nitrat $\left(\mathrm{NO}_{3}{ }^{-}\right)$, C-organik, dan KTK tanah, serta dapat mempertahankan produktivitas jagung di musim berikutnya. Serapan hara yang diamati pada penelitian ini merupakan akumulasi dari serapan hara berangkasan dan pipilan kering jagung (Biomass Total). Berdasarkan uji BNT pada taraf $5 \%$, pemupukan berpengaruh nyata terhadap serapan hara total tanaman jagung. Serapan hara N-total tertinggi terdapat pada perlakuan D sebesar $275,55 \mathrm{~kg} \mathrm{ha}^{-1}$, diikuti oleh perlakuan B (100\% NPK) sebesar 216,16 kg ha-1 yang tidak berbeda nyata dengan perlakuan kombinasi $\mathrm{C}$ dan F (Tabel 4). Serapan hara K-total tertinggi juga terdapat pada perlakuan D yaitu sebesar $236,36 \mathrm{~kg} \mathrm{ha}^{-1}$ (Tabel 4).

Tingginya serapan hara $\mathrm{N}$ dan $\mathrm{K}$ ini melebihi takaran pupuk yang diberikan yaitu urea sebesar 150 $\mathrm{kg} \mathrm{ha}^{-1}$ dan $\mathrm{KCl} 100 \mathrm{~kg} \mathrm{ha}^{-1}$. Hal ini diduga disebabkan oleh kandungan $\mathrm{N}$ dan $\mathrm{K}$ tanah yang tinggi. Berdasarkan 


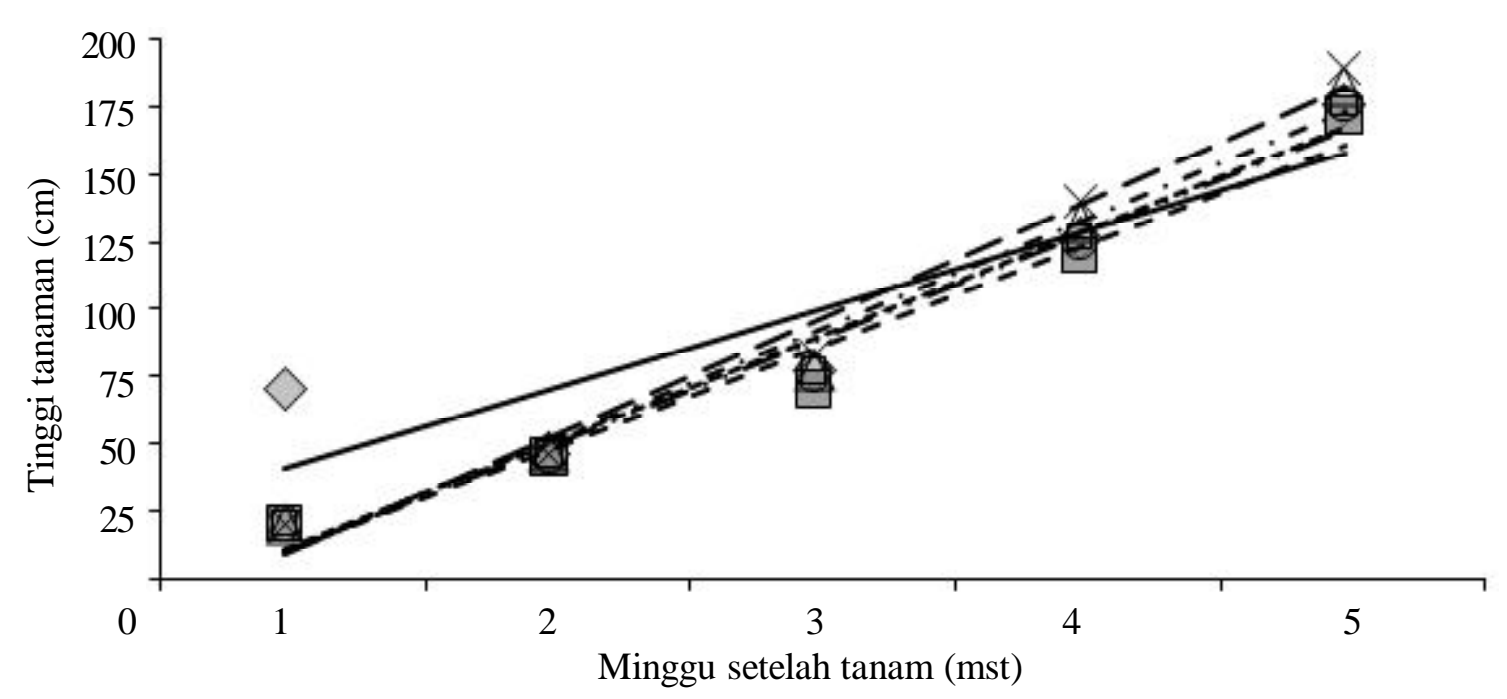

Gambar 1. Pengaruh aplikasi pupuk Organonitrofos dan kombinasinya dengan pupuk anorganik terhadap tinggi tanaman jagung pada masa vegetatif akhir pada musim tanam ke dua. $\diamond=\mathrm{A}$ (tanpa pemupukan/ kontrol). $\mathrm{y}_{\mathrm{A}}=39,212 \mathrm{x}-25,072 ; \square=\mathrm{B}\left(900 \mathrm{~kg}\right.$ urea ha $\left.{ }^{-1}, 250 \mathrm{~kg} \mathrm{SP}-36 \mathrm{ha}^{-1}, 250 \mathrm{~kg} \mathrm{KCl} \mathrm{ha}{ }^{-1}\right) \cdot \mathrm{y}_{\mathrm{B}}=$ $37,853 \mathrm{x}-28,050 ; \Delta=\mathrm{C}\left(600 \mathrm{~kg}\right.$ urea ha ${ }^{-1}, 150 \mathrm{~kg} \mathrm{SP}-36 \mathrm{ha}^{-1}, 150 \mathrm{~kg} \mathrm{KCl} \mathrm{ha}{ }^{-1}, 500 \mathrm{~kg}$ Organonitrofos $\left.\mathrm{ha}^{-1}\right) \cdot \mathrm{y}_{\mathrm{C}}=42,547 \mathrm{x}-29,397 ; X=\mathrm{D}\left(150 \mathrm{~kg}^{\mathrm{urea}} \mathrm{ha}^{-1}, 50 \mathrm{~kg} \mathrm{SP}-36 \mathrm{ha}^{-1}, 100 \mathrm{~kg} \mathrm{KCl} \mathrm{ha}{ }^{-1}, 1.000 \mathrm{~kg}\right.$ Organonitrofos ha-1). $\mathrm{y}_{\mathrm{D}}=45,543 \mathrm{x}-32,583 ; \square=\mathrm{E}\left(100 \mathrm{~kg}^{\mathrm{urea} \mathrm{ha}}{ }^{-1}, 50 \mathrm{~kg} \mathrm{SP}-36 \mathrm{ha}^{-1}, 100 \mathrm{~kg} \mathrm{KCl} \mathrm{ha}^{-1}\right.$, $2.000 \mathrm{~kg}$ Organonitrofos ha-1 $) \cdot \mathrm{y}_{\mathrm{E}}=39,644 \mathrm{x}-28,151 ; \mathrm{O}=\mathrm{F}(3.000 \mathrm{~kg}$ Organonitrofos ha-1 $) \cdot \mathrm{y}_{\mathrm{F}}=38,802 \mathrm{x}-$ 26,248 .

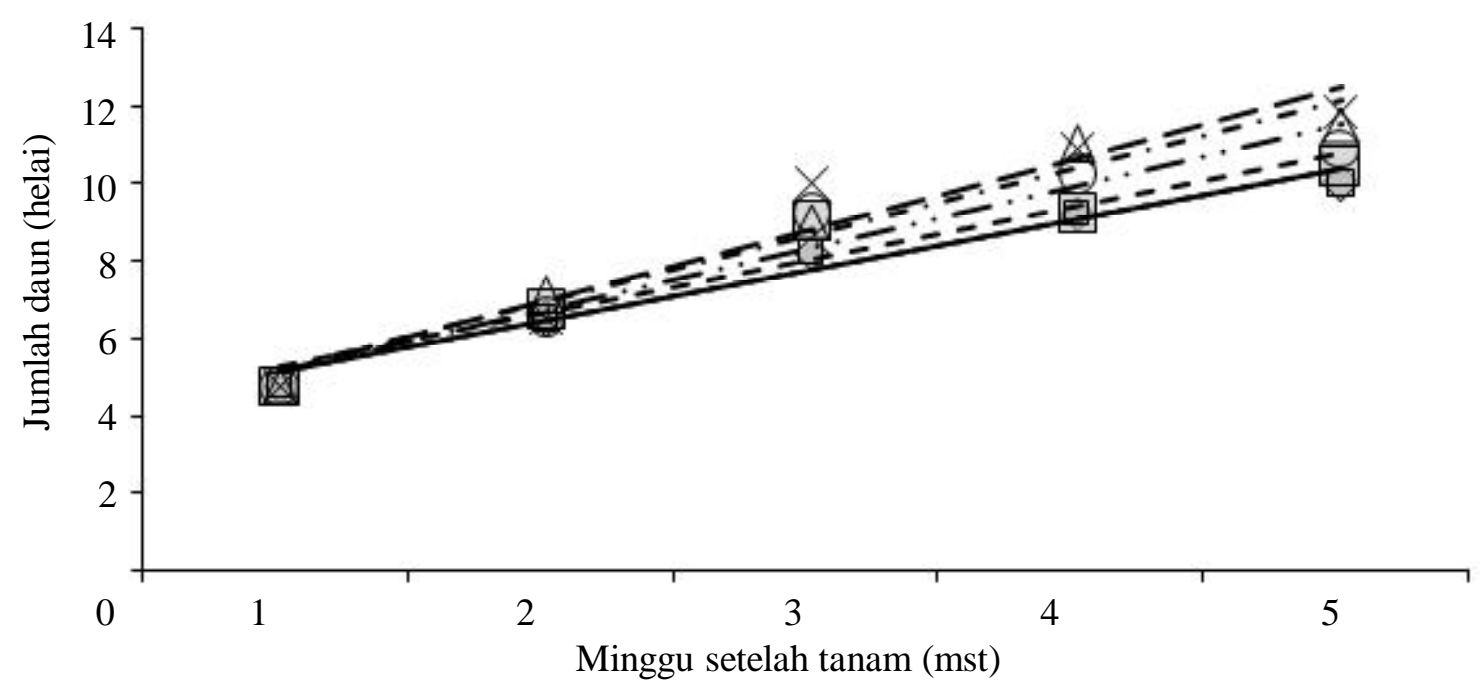

Gambar 1. Pengaruh aplikasi pupuk Organonitrofos dan kombinasinya dengan pupuk anorganik terhadap tinggi tanaman jagung pada masa vegetatif akhir pada musim tanam ke dua. $\diamond=\mathrm{A}$ (tanpa pemupukan/ kontrol). $\mathrm{y}_{\mathrm{A}}=1,4933 \mathrm{x}+3,5533$; $\square=\mathrm{B}\left(900 \mathrm{~kg}\right.$ urea ha- $\left.{ }^{-1}, 250 \mathrm{~kg} \mathrm{SP}-36 \mathrm{ha}^{-1}, 250 \mathrm{~kg} \mathrm{KCl} \mathrm{ha}{ }^{-1}\right) \cdot \mathrm{y}_{\mathrm{B}}=$ $1,3733 \mathrm{x}+3,5400 ; \Delta=\mathrm{C}\left(600 \mathrm{~kg}\right.$ urea ha ${ }^{-1}, 150 \mathrm{~kg} \mathrm{SP}-36 \mathrm{ha}^{-1}, 150 \mathrm{~kg} \mathrm{KCl} \mathrm{ha}{ }^{-1}, 500 \mathrm{~kg}$ Organonitrofos $\left.\mathrm{ha}^{-1}\right) \cdot \mathrm{y}_{\mathrm{C}}=1,6733 \mathrm{x}+3,7667 ; \times=\mathrm{D}\left(150 \mathrm{~kg}\right.$ urea ha-1, $50 \mathrm{~kg} \mathrm{SP}-36 \mathrm{ha}^{-1}, 100 \mathrm{~kg} \mathrm{KCl} \mathrm{ha}{ }^{-1}, 1.000 \mathrm{~kg}$ Organonitrofos ha-1). $y_{D}=1,7633 x+3,5433 ; \square=E\left(100 \mathrm{~kg}^{-1}\right.$ urea ha- ${ }^{-1}, 50 \mathrm{~kg} \mathrm{SP}-36 \mathrm{ha}^{-1}, 100 \mathrm{~kg} \mathrm{KCl}$ $\mathrm{ha}^{-1}, 2.000 \mathrm{~kg}$ Organonitrofos ha $\left.{ }^{-1}\right) . \mathrm{y}_{\mathrm{E}}=1,4667 \mathrm{x}+3,8000 ; \mathrm{O}=\mathrm{F}\left(3.000 \mathrm{~kg}\right.$ Organonitrofos $\left.\mathrm{ha}^{-1}\right)$. $\mathrm{y}_{\mathrm{F}}=1,5933 \mathrm{x}+3,5400$. 
Tabel 3. Bobot pipilan kering jagung pada kadar air 15\% setelah aplikasi pupuk Organonitrofos dan kombinasinya dengan pupuk anorganik pada musim tanam ke dua $\left(\mathrm{t} \mathrm{ha}^{-1}\right)$.

\begin{tabular}{|c|c|c|c|c|c|c|}
\hline \multirow[b]{2}{*}{ Perlakuan } & \multicolumn{3}{|c|}{ Kelompok } & \multirow{2}{*}{ Total } & \multirow[b]{2}{*}{ Rata- rata } & \multirow[b]{2}{*}{$\pm \mathrm{SD}$} \\
\hline & 1 & 2 & 3 & & & \\
\hline A (tanpa pemupukan) & 5,83 & 7,31 & 7,74 & 20,88 & 6,96 & 1,00 \\
\hline $\begin{array}{l}\text { B }\left(900 \mathrm{~kg} \mathrm{urea} \mathrm{ha}^{-1}, 250 \mathrm{~kg} \mathrm{SP}-36 \mathrm{ha}^{-1}, 250\right. \\
\left.\mathrm{kg} \mathrm{KCl} \mathrm{ha}^{-1}\right)\end{array}$ & 8,38 & 7,32 & 7,24 & 22,94 & 7,65 & 0,63 \\
\hline $\begin{array}{l}\mathrm{C}\left(600 \mathrm{~kg}^{-1} \text { ure ha }{ }^{-1}, 150 \mathrm{~kg} \text { SP-36 ha- } \mathrm{ha}^{-1}, 150\right. \\
\mathrm{kg} \mathrm{KCl} \mathrm{ha}, 500 \mathrm{~kg} \text { Organonitrofos ha }\end{array}$ & 6,74 & 8,51 & 7,75 & 23,00 & 7,67 & 0,89 \\
\hline $\begin{array}{l}\text { D (150 kg urea ha- }{ }^{-1}, 50 \mathrm{~kg} \mathrm{SP-36} \mathrm{ha-}{ }^{1}, 100 \\
\left.\mathrm{~kg} \mathrm{KCl} \mathrm{ha-}^{-}, 1.000 \mathrm{~kg} \text { Organonitrofos } \mathrm{ha}^{-1}\right)\end{array}$ & 8,27 & 7,69 & 7,24 & 23,20 & 7,73 & 0,52 \\
\hline $\begin{array}{l}\text { E }\left(100 \mathrm{~kg} \text { urea ha- }{ }^{1}, 50 \mathrm{~kg} \text { SP-36 ha- }{ }^{1}, 100\right. \\
\left.\mathrm{kg} \mathrm{KCl} \mathrm{ha-}{ }^{1}, 2.000 \mathrm{~kg} \text { Organonitrofos ha- }{ }^{1}\right)\end{array}$ & 8,49 & 7,54 & 7,03 & 23,06 & 7,69 & 0,74 \\
\hline F (3.000 kg Organonitrofos $\left.\mathrm{ha}^{-1}\right)$ & 6,98 & 7,70 & 7,57 & 22,24 & 7,41 & 0,38 \\
\hline Jumlah & 44,69 & 46,07 & 44,57 & 135,33 & 45,11 & 4,16 \\
\hline Rata-rata & 7,45 & 7,68 & 7,43 & 22,55 & 7,52 & 0,69 \\
\hline
\end{tabular}

Tabel 4. Pengaruh aplikasi pupuk Organonitrofos dan kombinasinya dengan pupuk anorganik terhadap serapanhara $\mathrm{N}$, P, dan K total tanaman jagung pada musim tanam ke dua.

\begin{tabular}{|c|c|c|c|}
\hline Perlakuan & $\begin{array}{l}\text { N Total } \\
\left(\mathrm{kg} \mathrm{ha}^{-1}\right)\end{array}$ & $\begin{array}{l}\text { P total } \\
\left(\mathrm{kg} \mathrm{ha}^{-1}\right)\end{array}$ & $\begin{array}{l}\text { K Total } \\
\left(\mathrm{kg} \mathrm{ha}^{-1}\right)\end{array}$ \\
\hline A (tanpa pemupukan) & $128,26 \mathrm{~d}$ & $20,75 \mathrm{c}$ & $86,01 \mathrm{~d}$ \\
\hline B (900 kg urea ha $\left.{ }^{-1}, 250 \mathrm{~kg} \mathrm{SP}-36 \mathrm{ha}^{-1}, 250 \mathrm{~kg} \mathrm{KCl} \mathrm{ha}{ }^{-1}\right)$ & $216,16 b$ & $34,50 \mathrm{~b}$ & $157,08 \mathrm{~b}$ \\
\hline $\begin{array}{l}\mathrm{C}(600 \mathrm{~kg} \text { urea ha } \\
\left.\text { kg Organonitrofos } \mathrm{ha}^{-1}\right) \\
\mathrm{kg} \text { kg SP-36 ha-1, } 150 \mathrm{~kg} \mathrm{KCl} \mathrm{ha}^{-1}, 500\end{array}$ & $209,02 \mathrm{~b}$ & $33,04 \mathrm{~b}$ & $141,55 \mathrm{bc}$ \\
\hline $\begin{array}{l}\mathrm{D}\left(150 \mathrm{~kg} \text { urea ha- }{ }^{1}, 50 \mathrm{~kg} \mathrm{SP}-36 \mathrm{ha}^{-1}, 100 \mathrm{~kg} \mathrm{KCl} \mathrm{ha-}{ }^{1}, 1.000\right. \\
\left.\mathrm{kg} \text { Organonitrofos } \mathrm{ha}^{-1}\right)\end{array}$ & $275,55 \mathrm{a}$ & $43,15 \mathrm{a}$ & 236,36 a \\
\hline $\begin{array}{l}\text { E (100 kg urea ha- }{ }^{1}, 50 \mathrm{~kg} \mathrm{SP}-36 \mathrm{ha}^{-1}, 100 \mathrm{~kg} \mathrm{KCl} \mathrm{ha-}{ }^{1}, 2.000 \\
\left.\mathrm{~kg} \text { Organonit rofos } \mathrm{ha}^{-1}\right)\end{array}$ & $185,56 \mathrm{bc}$ & $35,84 \mathrm{~b}$ & $138,59 \mathrm{~b}$ \\
\hline $\mathrm{F}\left(3.000 \mathrm{~kg}\right.$ Organonitrofos $\left.\mathrm{ha}^{-1}\right)$ & $158,51 \mathrm{~cd}$ & $31,95 \mathrm{~b}$ & $114,35 \mathrm{c}$ \\
\hline BNT 0,05 & 36,25 & 5,63 & 26,75 \\
\hline
\end{tabular}

Keterangan: Angka yang diikuti huruf yang sama tidak berbeda nyata pada uji BNT taraf 5\%.

analisis tanah awal, kandungan $\mathrm{N}$-total tanah pada perlakuan D sebesar 0, 24\% sedangkan K-dd tanah sebesar $0,76 \mathrm{cmol} \mathrm{kg}^{-1}$ (Tabel 1).

Serapan P-total tertinggi sebesar $43,15 \mathrm{~kg} \mathrm{ha}^{-1}$ juga terdapat pada perlakuan $\mathrm{D}$ dengan dosis $150 \mathrm{~kg}$ urea ha ${ }^{-1}, 50 \mathrm{~kg} \mathrm{SP}-36 \mathrm{ha}^{-1}, 100 \mathrm{~kg} \mathrm{KCl} \mathrm{ha}{ }^{-1}, 1.000 \mathrm{~kg}$ Organonitrofos ha ${ }^{-1}$ (Tabel 4). Hal ini menunjukkan bahwa perlakuan D mampu meningkatkan ketersediaan $\mathrm{P}$ dalam larutan tanah sehingga mampu meningkatkan serapan P oleh tanaman. Perlakuan B dengan dosisi N,
$\mathrm{P}$, dan $\mathrm{K}$ tunggal memperoleh hasil yang tidak berbeda nyata dengan perlakuan C, E dan F (Tabel 5). Serapan P-total tanaman yang meningkat pada perlakuan D berhubungan dengan ketersediaan $\mathrm{P}$ dalam tanah. Adapun ketersediaan $\mathrm{P}$ dalam tanah berasal dari pupuk SP-36 dan pupuk Organonitrofos yang mengandung bahan organik berupa kotoran sapi segar.

Berdasarkan hasil penelitian, perlakuan D dengan dosis $150 \mathrm{~kg}$ urea ha- ${ }^{-1}, 50 \mathrm{~kg} \mathrm{SP}-36 \mathrm{ha}^{-1}, 100 \mathrm{~kg} \mathrm{KCl}$ $\mathrm{ha}^{-1}, 1.000 \mathrm{~kg}$ Organonitrofos ha-1 menunjukkan hasil 
pertumbuhan, produksi serta serapan hara tertinggi. Peningkatan pertumbuhan, produksi, serta serapan hara tertinggi pada perlakuan D menandakan bahwa perlakuan D mampu menciptakan kondisi media tumbuh yang baik daripada perlakuan lainnya. Yusnaini, dkk. (2004) menyatakan bahwa selama 2 musim tanam pertanaman jagung, kombinasi pupuk anorganik dengan pupuk organik dosis $20 \mathrm{t} \mathrm{ha}^{-1}$ mampu memperbaiki produktivitas lahan sehingga produksi tanaman jagung meningkat.

Berdasarkan uji korelasi, terdapat korelasi antara serapan hara dengan pertumbuhan dan produksi tanaman jagung. Serapan hara N, P dan K total berkorelasi dengan tinggi tanaman, bobot pipilan dan bobot berangkasan kecuali antara serapan $\mathrm{P}$ dengan tinggi tanaman (Tabel 5). Hal ini dikarena peningkatan serapan hara $\mathrm{P}$ total tanaman tidak diikuti dengan peningkatan tinggi tanaman jagung. Namun tidak demikian antara serapan P-total dengan bobot pipilan kering, karena semakin tinggi serapan P maka semakin tinggi pula bobot pipilan kering jagung, begitu juga dengan $\mathrm{N}$ dan $\mathrm{K}$ terhadap tinggi tanaman serta $\mathrm{N}, \mathrm{P}$, dan $\mathrm{K}$ terhadap bobot berangkasan.

Cara untuk membandingkan keefektivan pupuk adalah dengan Relative Agronomic Effectiviness (RAE). RAE yaitu membandingkan antara kenaikan hasil penggunaan pupuk yang sedang diuji dengan kenaikan hasil pada pupuk standar rekomendasi dikalikan $100 \%$, apabila nilai RAE e" 100 maka pupuk yang diuji bersifat efektif dibanding perlakuan (pupuk) standar (Permentan no. 70, 2011). Bobot biomass total yang digunakan terdiri dari bobot pipilan kering KA $15 \%$ dan bobot berangkasan tanaman.

Tabel 5. Uji korelasi antara serapan hara N, P, dan K dengan tinggi tanaman, bobot pipilan, dan bobot berangkasan pada musim tanam ke dua.

\begin{tabular}{clll}
\hline No & \multicolumn{1}{c}{ Uji Korelasi } & \multicolumn{1}{c}{ Persamaan } & $\mathrm{r}$ \\
\hline 1 & Serapan N dengan tinggi tana man & $\mathrm{y}=0,1553 \mathrm{x}+155,38$ & $0,464 *$ \\
2 & Serapan P dengan tinggi tanaman & $\mathrm{y}=0,9683 \mathrm{x}+153,59$ & $0,416 \mathrm{tn}$ \\
3 & Serapan K dengan tinggi tana man & $\mathrm{y}=0,1604 \mathrm{x}+162,38$ & $0,468 *$ \\
4 & Serapan N dengan bobot pipilan kering & $\mathrm{y}=0,0074 \mathrm{x}+6,078$ & $0,555^{*}$ \\
5 & Serapan P dengan bobot pipilan kering & $\mathrm{y}=0,0598 \mathrm{x}+5,531$ & $0,649 *$ \\
6 & Serapan K dengan bobot pipilan kering & $\mathrm{y}=0,0063 \mathrm{x}+6,603$ & $0,462 *$ \\
7 & Serapan N dengan bobot berangkasan & $\mathrm{y}=0,0188 \mathrm{x}+3,471$ & $0,606 *$ \\
8 & Serapan P dengan bobot berangkasan & $\mathrm{y}=0,1020 \mathrm{x}+3,766$ & $0,472 *$ \\
9 & Serapan K dengan bobot berangkasan & $\mathrm{y}=0,0182 \mathrm{x}+4,495$ & $0,573 *$ \\
\hline
\end{tabular}

Keterangan : $\mathrm{tn}=$ tidak nyata, $*=$ nyata pada taraf $5 \%$

Tabel 6. Perhitungan Relative Agronomic Effectiviness (RAE) pada bobot biomass total tanaman jagung pada musim tanam ke dua.

\begin{tabular}{|c|c|}
\hline Perlakuan & RAE Biomass Total (\%) \\
\hline A (tanpa pemupukan) & - \\
\hline B (900 kg urea ha $\left.{ }^{-1}, 250 \mathrm{~kg} \mathrm{SP}-36 \mathrm{ha}^{-1}, 250 \mathrm{~kg} \mathrm{KCl} \mathrm{ha}{ }^{-1}\right)$ & 100 \\
\hline $\begin{array}{l}\mathrm{C}(600 \mathrm{~kg} \text { urea ha } \\
\left.\text { Organonitrofos } \mathrm{ha}^{-1}\right) \\
\text { Org }\end{array}$ & 60,49 \\
\hline $\begin{array}{l}\text { D (150 kg urea ha- }{ }^{1}, 50 \mathrm{~kg} \mathrm{SP}-36 \mathrm{ha}^{-1}, 100 \mathrm{~kg} \mathrm{KCl} \mathrm{ha-}{ }^{1}, 1.000 \\
\left.\mathrm{~kg} \text { Organonit rofos } \mathrm{ha}^{-1}\right)\end{array}$ & 125,33 \\
\hline $\begin{array}{l}\text { E (100 kg urea ha- }{ }^{1}, 50 \mathrm{~kg} \mathrm{SP}-36 \mathrm{ha}^{-1}, 100 \mathrm{~kg} \mathrm{KCl} \mathrm{ha-}{ }^{1}, 2.000 \mathrm{~kg} \\
\left.\text { Organonitrofos ha- }{ }^{1}\right)\end{array}$ & 98,60 \\
\hline $\mathrm{F}\left(3.000 \mathrm{~kg}\right.$ Organonitrofos $\left.\mathrm{ha}^{-1}\right)$ & 50,03 \\
\hline
\end{tabular}


Hasil perhitungan RAE (Tabel 6) menunjukkan bahwa perlakuan D dengan dosis kombinasi $150 \mathrm{~kg}$ urea $\mathrm{ha}^{-1}, 50 \mathrm{~kg} \mathrm{SP}-36 \mathrm{ha}^{-1}, 100 \mathrm{~kg} \mathrm{KCl} \mathrm{ha}{ }^{-1}, 1.000 \mathrm{~kg}$ Organonitrofos ha-1 bersifat paling efektif dibandingkan pupuk standar dengan dosis $900 \mathrm{~kg}$ urea ha ${ }^{-1}, 250 \mathrm{~kg}$ SP-36 ha- ${ }^{-1}, 250 \mathrm{~kg} \mathrm{KCl} \mathrm{ha}^{-1}$. Berbeda dengan penelitian musim tanam pertama, perlakuan $100 \mathrm{~kg}$ urea $\mathrm{ha}^{-1}, 50$ $\mathrm{kg} \mathrm{SP}-36 \mathrm{ha}^{-1}, 100 \mathrm{~kg} \mathrm{KCl} \mathrm{ha}^{-1}, 2.000 \mathrm{~kg}$ Organonitrofos $\mathrm{ha}^{-1}(\mathrm{E})$ menunjukkan nilai RAE tertinggi (Septima, 2013). Hasil ini menunjukkan aplikasi pupuk Organonitrofos yang dikombinasikan dengan pupuk anorganik mampu menunjang pertumbuhan serta produksi tanaman jagung, sehingga dalam pengaplikasian pupuk anorganik dapat dikombinasikan dengan pupuk Organonitrofos.

\section{KESIMPULAN}

Berdasarkan penelitian yang dilakukan perlakuan dengan dosis kombinasi $150 \mathrm{~kg}$ urea ha ${ }^{-1}+50 \mathrm{~kg}$ SP-36 $\mathrm{ha}^{-1}+100 \mathrm{~kg} \mathrm{KCl} \mathrm{ha}{ }^{-1}+1000 \mathrm{~kg}$ organonitrofos ha- ${ }^{-1}$ mampu meningkatkan pertumbuhan, produksi, serta serapan hara $\mathrm{N}$, $\mathrm{P}$, dan $\mathrm{K}$ total tertinggi pada tanaman jagung dan paling efektif terhadap biomass total tanaman jagung berdasarkan perhitungan Relative Agronomic Effectiveness. Serta terdapat korelasi antara serapan hara $\mathrm{N}, \mathrm{P}$, dan $\mathrm{K}$ dengan tinggi tanaman, bobot pipilan kering serta bobot berangkasan tanaman, kecuali antara serapan $\mathrm{P}$ dengan tinggi tanaman.

\section{SANWACANA}

Penulis mengucapkan terima kasih kepada Direktorat Jendral Pendidikan Tinggi yang telah memberikan dana Riset Unggulan Strategis Nasional Tahun 2011-2013.

\section{DAFTAR PUSTAKA}

Adnan, A. M., C. Rapar, dan Zubachtirodin. 2010. Deskripsi Varietas Unggul Jagung. Balai Penelitian Tanaman Serealia. 118 Hlm.

Badan Pusat Statistik. 2013. Produksi Tanaman Palawija. Diakses dari http://lampung.bps.go.id. Diakses tanggal 11 November 2013.

FAO. 1983. Reconnaissance Land Resource Surveys. Ministry of Agriculture Government of Indonesia. $112 \mathrm{Hlm}$.

Ma, B.L., L.M. Dwyer, and E.G. Gregorich. 2006. Soil Nitrogen Amendment Effects on Seasonal
Nitrogen Mineralization and Nitrogen Cycling in Maize Production. J. Agron. 91: 1003-1009.

Nugroho, S.G., Dermiyati, J. Lumbanraja, S. Triyono, H. Ismono, Y. T. Sari, and E. Ayuandari. 2012. Optimum Ratio of Fresh Manure and Grain Size of Phosphate Rock Mixture in a Formulated Compost for Organomineral NP Fertilizer. $J$. Trop. Soils 17(2): 121-128.

Nugroho, S.G., Dermiyati, J. Lumbanraja, S. Triyono, H. Ismono, M. K. Ningsih, and F. Y. Saputri. 2013. Inoculation Effect $\mathrm{Of} \mathrm{N}_{2}$-Fixer and $\mathrm{P}$ Solubilizer into a Mixture of Fresh Manure and Phosphate Rock Formulated as Organonitrofos Fertilizer on Bacterial and Fungal Populations. $J$. Trop. Soils 18(1): 75-80.

Nursyamsi, D., J. S. Adiningsih, Sholeh, dan A. Adimihardja. 1996. Penggunaan Bahan Organik untuk Meningkatkan Efisiensi Pupuk N dan Produktivitas Tanah Ultisolss di Sitiung, Sumbar. J. Tanah Tropika (2): 26-33.

Permentan. 2011. Metode Pengujian Efektivitas Pupuk Organik. Peraturan Menteri Pertanian no: 70/ Permentan/SR.140/10/2011.

Prasetyo, B. H. dan D.A. Suriadikarta. 2006. Karakteristik, Potensi, Dan Teknologi Pengelolaan Tanah Ultisols untuk Pengembangan Pertanian Lahan Kering di Indonesia. J. Litbang Pertanian 25(2): 39-47.

Septima, A.R. 2013. Uji Efektivitas Pupuk Organonitrofos dan Kombinasinya dengan Pupuk Kimia terhadap Pertumbuhan, Produksi Tanaman Jagung. Skripsi. Universitas Lampung. Bandar Lampung. $87 \mathrm{Hlm}$.

Soekartawi. 1995. Teori Ekonomi Produksi. Rajawali Pers. Jakarta. $257 \mathrm{Hlm}$.

Suratmi, P. 2009. Kombinasi Pemupukan Urea dan Pupuk Organik pada Jagung Manis di Lahan Kering. J. Penelitian Pertanian Tanaman Pangan 28(2): 83-88.

Wigati, E.S., S. Abdul, dan D. K. Bambang. 2006. Pengaruh Takaran Bahan Organik dan Tingkat Kelengasan Tanah terhadap Serapan Fosfor oleh Kacang Tunggak di Tanah Pasir Pantai. J. Ilmu Tanah dan Ling. 6(1): 52-58.

Yulnafatmawita, Adrinal, dan A.F., Hakim. 2011. Pencucian Bahan Organik Tanah pada Tiga Penggunaan Lahan di Daerah Hutan Hujan Tropis 
Super Basah Pinang-Pinang Gunung Gadut Padang. J. Solum 8(1): 34-42.

Yusnaini, S., M. A. S. Arif, J. Lumbanraja, S.G. Nugroho, dan M. Nonaka. 2004. Pengaruh Jangka Panjang Pemberian Pupuk Organik dan Inorganik serta Kombinasinya terhadap Perbaikan Tanah Masam Taman Bogo. J. Tanah Trop. 18(1): 155-162.
Yusnaini, S. 2009. Keberadaan Mikoriza Vesikular Arbuskular pada Pertanaman Jagung yang Diberi Pupuk Organik dan Anorganik Jangka Panjang. J. Tanah Trop. 14(3): 253-256. 